\title{
The politics of religious dualism: Naim Frashëri and his elective affinity to religion in the course of 19th-century Albanian activism
}

Social Compass

60 (1) $115-133$

(C) The Author(s) 2013 Reprints and permissions: sagepub.co.uk/journalsPermissions.nav DOI: I0.1।77/00377686/247|770 scp.sagepub.com

@SAGE

\author{
Albert DOJA \\ University of Sciences and Technologies of Lille I, France
}

\begin{abstract}
In standard Albanian studies and Western scholarship, including both the work of religious and political activists and that of less 'interested' lay people, historical and textual fact-finding efforts have only confirmed and indeed perpetuated the myth that the thinking of Naim Frashëri was formed and dominated by Bektashism and that his 'Albanianism' had a Bektashi foundation. The author intends to scrutinize and disprove this analysis, arguing that while Frashëri's thinking did indeed have a religious cast, it went far beyond Bektashism in its heterodoxy, being a kind of liberation theology and pantheism, which generated an all-inclusive attitude to Albanian identity, not one limited in any particular way to Bektashism. Methodologically, such a picture must arise if we submit the available empirical evidence to critical analysis from the perspective of social theoretical approaches to religion developed in sociology and anthropology.
\end{abstract}

\section{Keywords}

Albania, Bektashi, heterodoxy, liberation theology, myth, Naim Frashëri, nationalism, religious dualism, Sufism

\section{Résumé}

Dans la tradition des études albanaises et occidentales les plus courantes, que ce soit au travers de l'activisme religieux et politique intéressé ou de celui moins «intéressé » des gens ordinaires, les efforts de recherche relatifs aux faits historiques et textuels

\footnotetext{
Corresponding author:

Albert DOJA, Institute of Sociology and Anthropology, University of Sciences and Technologies of Lille I, Clersé - UMR CNRS 8019, Cité Scientifique SH2-215, 59655 Villeneuve d'Ascq Cedex, France.

Email: albert.doja@univ-lillel.fr
} 
n'ont fait que confirmer et perpétuer la signification même d'un mythe, selon lequel la pensée de Naim Frashëri a été formée et dominée par le Bektachisme et selon lequel son «Albanisme» avait un fondement bektachi. L'auteur propose de questionner et réfuter cette analyse, en argumentant le fait que tandis que la pensée de Frashëri avait en effet un fond religieux, elle s'est fortement éloignée du Bektashisme dans son hétérodoxie, se présentant comme une sorte de théologie de la libération et de panthéisme, qui a suscité une attitude incluant l'identité albanaise comme un tout, sans se limiter spécialement au Bektashisme. Méthodologiquement, cette nouvelle façon de voir les choses pourra se révéler si nous soumettons l'évidence empirique disponible à une analyse critique dans la perspective des approches socio-théoriques de la religion telles qu'elles sont développées en sociologie et en anthropologie.

\section{Mots-clés}

Albanie, bektachi, dualisme religieux, hétérodoxie, mythe, Naim Frashëri, nationalisme, soufisme, théologie de la libération

\section{Introduction}

The question of how religion and nationalism are linked is theoretically important, and for students with a passion for the 'thick and the thin' (Geertz, 1973b) of that disputatious field, the link between religious division and nationalism in the Albanian context is interesting for its potential to contribute to our understanding of how the dynamic interplay between religion and social movements is articulated and how nationalist myths are constructed. Nationalist ideas use different 'cultural stuff' to legitimize their objectives (Barth, 1969) and religion is one among a set of possible markers for nationalist ideologies. However, the way the Albanian national 'renaissance' (Rilindja) developed after the predictable fall of the Ottoman Empire, in a period extending from the mid-19th century to the Declaration of Independence in 1912, showed that language and history were the most important cultural stuff to argue for common 'essential' and 'authentic' Albanian values and demarcate national boundaries. By contrast, the attractive force of religion in providing a universal and transcendent foundation to collective association had to be inverted and considered counterproductive in shaping a national identity myth (Doja, 1999). Even though religious shifting must have been instrumental in the reconstruction of identities in multi-religious Albania (Doja, 2000b), religious division was a threat to Albanian unity. In this extremely difficult period for the assertion of Albanian national identity, a great number of Albanian Muslims, despite their 'divided loyalty' (Skendi, 1967: 469-470), often firmly expressed the will to sever links with the Ottoman Empire (Bartl, 1968). Among others, the political position of Bektashis is particularly revealing.

Bektashism is surely one of the most unusual and important Sufi orders in the Balkans and in Anatolia. From various developments during the later centuries of the Ottoman Empire it became obvious that Western Balkan and Albanian-speaking areas often served as a kind of exile for the adherents of the Bektashi order, and there is general agreement that after the noticeable increase in their presence in the second half of 17th century, Bektashism gradually became deeply rooted in the area towards the end of 19th century, 
to the extent of becoming the most important Islamic mystical order. It is claimed in particular, not only by Bektashi leaders (Turabiu, 1929; Rexhebi, 1970) but also by modern scholars of Bektashism (Popovic, 1986; Clayer, 1990; Popovic and Veinstein, 1995; Norton, 2001; Kressing, 2002), that the order has served as one of the pillars of either elite or popular religiosity for the Albanian-speaking people and that it must have played a proud and, comparatively speaking, remarkable role in shaping Albanian nationalism in late 19th and early 20th centuries.

What was traditionally assumed to have been a difficult relationship between Bektashism and the religious and political Ottoman authorities is said to have contributed to its choice of an anti-Turk and nationalist stance in Albania (Morozzo della Rocca, 1990). However, it can be argued that this must have gone along with a reinforcement of heterodoxy characteristic of its system of beliefs and practices. It is certainly not surprising that Naim Frashëri (1846-1900) was particularly instrumental in that development. He is better known as the greatest Albanian poet and activist of the Albanian nationalist movement in the 19th century, striving to establish a unified written Albanian language and glorify the Albanian past in a literature of his own. With its strong moralist and nationalist pathos his work is considered to have overcome the various religious, sociocultural and dialectal divisions on which the writings of his predecessors were based. That is why, much more than any other activism, his creative writing is believed to have inspired Albanian national union and to have helped the self-affirmation of the Albanian-speaking people as a modern nation. At the same time, not only did he contribute to Bektashi literature but he also explained and promoted, and to some extent even founded, in his Bektashi Notebook (1896), the novel theological and practical principles of Bektashism and the organizational rules governing its functioning.

Methodologically, the reference to divided loyalties does not necessarily suggest a dichotomist formulation of Frashëri being either a Bektashi Muslim or an Albanian nationalist. This dichotomy was not present in the thinking of Albanian intellectuals, at least not around the time of Frashëri's work and activism. People in that era were often both, just as not all Albanian Bektashis were anti-Ottoman. Many Albanian Sunni Muslims and Orthodox Christians, even Albanian Catholics, were entrenched Ottoman loyalists as well. Indeed, in local scholarship of either a religious or a nationalist cast there is little room for the notion of multiple and overlapping identities, whereas we must recognize Frashëri's long and distinguished career in the service of the Ottoman State, as well as his own and his younger brother's monumental contributions to Turkish language and culture. This is especially intriguing if we recall that Frashëri was first not related to any national identity politics at all, even at the time of the League of Prizren (18781881), which is considered to be the founding event of Albanian nationalism and of which his elder brother was one of the most prominent leaders. From a dreamy individual, still deeply lost in the gloomy lyrics of his 'Reveries' in Persian (Tehayyülat, 1884), and a zealous official of State administration with many links of loyalty to Ottoman power, he suddenly turned himself into the most brilliant promoter of the Albanian language and the most influential activist of the Albanian national movement, in flagrant opposition to the politics of the Ottoman regime.

This does not rule out exclusionary dichotomy in the thinking of Frashëri with regard to Ottomans and Albanianism, but we need subtler and historically more meaningful 
terms to accurately position people like Frashëri. Whatever term we think of, his personal position must fit with an emphasis on the universalistic dimensions of his intellectual orientation, just as in the case of his younger brother, whose works generally combined Oriental and Western writing styles. Frashëri must have subsumed and reconciled in his work different philosophical currents of thought and poetic experiences, coming from either Eastern or Western traditions, as an author and thinker who was consciously open to all cultures and civilizations, and freed from any Eurocentric or Asia-centric complex.

In this connection, some qualification of the supposed Bektashi background and inspiration of his work and activism does not necessarily diminish his commitment to both Bektashism and Albanianism. On the contrary, the analysis presented here is aimed to introduce innovative methodology into the study of the relationship of religious identity to political mobilization, with a potential to bring forth insights for understanding the situation in which group identities are negotiated and redefined.

The liberating character of heterodox religious movements and the institution of new forms of religion, as in the case of mystical orders of Islam like Bektashism, are decisive for understanding the history and social dimensions of religions in the context of Albanian nationalism. Mystics may not partake in or directly express community struggle. However, their heterodoxy, over and above the intensity and power of their beliefs or the radical character of their opposition to the established religion, may well crystallize political, social and cultural discontent. In turn, this is very often either ethnicized along nationalist lines or politicized in terms of power forces or both. As in discourses related to the Muslim religious revival, confraternal or otherwise, one recurrently finds nationalist motives, which better illustrate the necessity of considering such a powerful mobilizing force in the role that religious leaders claim they play in this field. The point is not only that religion as a cultural symbolic system uses resources that show a power base. More importantly, in its own field, religion has a symbolic structure, which, as Bourdieu (1971) put it, reproduces the distribution of resources and power from the non-symbolic mundane field in a transformed form.

Surely, the constant tension that subsists between orthodoxy and mystical movements is not exclusive to Islam. The polemic against sects and heterodox religious movements is primarily and essentially expressed in terms of conflict on doctrinal grounds. However, if the sociological perspective points to the socioeconomic roots of religious movements, it tends to underestimate the importance of the religious organizational structure, while the ideological and doctrinal field has been left exclusively in the hands of theologians, and has occasionally disputed by Orientalist and Medievalist historians. Yet the particular affinity that sociologists and anthropologists show between new religious movements and social, cultural and national crisis movements, as well as the extent to which religious ideas must be regarded either as a justification for liberationist movements or as an ideology justifying domination, may be better appreciated if we bear in mind the underlying significance of the structures of religious representation and mediation examined elsewhere (Doja, 2000a) and the implication of their change in support of either cultural orderings or order-questioning projects in human society.

Both sociological conceptions of the role of religious faith, orthodoxy and liberation, are not, by any means, mutually exclusive or essentially contradictory. There are not two kinds of behaviour set once and for all, nor is there merely a 'routinization' in a Weberian 
sense (1978: 246-254), but rather a process of dialectic change and transformation. As political conditions change and the organization of religious structures undergoes a number of transformations, the assumption is that the essential differences between types of theology, namely heterodoxy and orthodoxy, must change and adapt accordingly.

The transition from innovation to conservatism in theological conceptions and organizational structures, and the subsequent renewal of innovation, in support of either liberating social and national movements or the re-establishment of a new political power in society, takes on different forms and tones. The threefold expression of the experience of the sacred described by Joachim Wach (1958), for instance, or the establishment of sectarianism at the second generation of followers argued by Bryan Wilson (1990) may be considered as actualizations of this complex process that requires in each case detailed historical and political analysis of the cultural values and social entities involved.

In fact, the analysis of instrumental transformations in doctrinal-ideological and structural-organizational patterns that are clearly evidenced by the development of Bektashism down its history, depending on different political contexts and the course of events - as much in the classical Ottoman period, in the reformed Ottoman system or in modern Turkey as in independent Albania or in the Albanian post-communist period, which I examined elsewhere (Doja, 2006a, 2006b) - is an illustrative suggestion that it is precisely on these structural and ideological grounds that the correlation between religious innovation and political projects may be correctly addressed. In this wake, Frashëri's intellectual speculations in the context of the Albanian national movement examined here must be situated in the stage of development of religious ideas that must have corresponded to the promotion of the historical heterodox traits of Bektashism as a liberation theology.

After a brief outline of the Bektashi background that is supposed to have provided some inspiration to Frashëri's work and activism, the historical and literary contextualization of his major works closely related to Bektashism is analyzed in an attempt to clarify some peculiarities of the Albanian context, namely the separation of religious and ethnic elements as a distinctive feature of Albanian nationalism, and to illustrate the inadequacy of religious paradigms in conceiving Frashëri's nationalist project. On the way, I take issue with the speculative literalism in current scholarship that reconstructs and adapts the Bektashi myth to match the emergence of the Albanian national movement. This leads me to consider the specific heterodox traits of Bektashism as a liberation theology. Understanding how these ideological elements are emphasized in Frashëri's works should lead, against Bektashi claims supported by current scholarship, to an understanding of the way in which Bektashi symbolism is aimed to be deconfessionalized in conformity with an Albanian nationalism that transcended confessional allegiances.

\section{The Bektashi myth of Karbala}

In Bektashism and Shiite Islam, a founding value is attributed to the battle of Karbala, in which the Imam Hussein, son of Ali and grandson of Muhammad, was killed in 680AD. In this story the Prophetic continuation of supposed democratic and republican religious concepts, represented by the Imams and their followers, is assumed to have 
been destroyed by the autocratism of Muawiya (603-680), founder of the Umayyad dynasty of Damascus that ruled the Islamic world (660-750) and Moorish Spain (7561031). He is held to have arrogated a hierarchical dynastic principle of imperial rule deviating from caliphate religious egalitarianism. Bektashis, as Shiite Muslims (Ayoub, 1978), put great emphasis on keeping alive the memory of this tragic event through epic poetry, plays, processions, commemorative services and other mnemonic devices. The commemoration rituals of Hussein's martyrdom, the use of very direct language and imagery, the re-enactment of suffering, and the constant repetition of ideas serve as a basis for identity and community cohesion (Norris, 1993: 171-174).

Frashëri also retells the saga of Shiism in a monumental epic poem in 25 cantos (Qerbelaja, 1898), following a long-standing tradition of Eastern literature and philosophy. His poetic elaboration of the Karbala martyrdom marked the culmination of the quest by earlier Albanian poets to dramatically describe those events which the annual Bektashi celebration commemorated and which must have meant so much to the suppressed Albanian people. Above all, by relating to this seemingly religious but actually political confrontation, Frashëri tried to realize and promote his enlightened and liberating humanist ideas. He praised the Imam as the standard-bearer and champion of justice and liberation against the injustice of his tyrant and usurper adversaries, while declaring as an inexorable principle that in a battle between justice and injustice, liberation and tyranny, the outcome shows justice and liberation victorious. More than retelling historical events, Qerbelaja is a moralistic and intellectual record, a reformulation and promulgation of the principles of humanistic morality, an appeal for moral purity and perfection, for humankind to be able to enjoy earthly life and confront its reversal.

Surely, the Karbala martyrs were Muslims of the same faith as the Ottoman State religion. Nevertheless, it is astonishing how in Frashëri's Qerbelaja their martyrdom is turned into an Albanian inspiration against Ottoman subjugation. In actualizing retelling the events, Frashëri not only brought them into his own time but also gave them the reality he imagined, so that his formulation of these notions must be considered in the light of his overall poetic and moral speculations: the Karbala battle is thought of as the Albanian fight against Ottoman power and, in their battle, Albanians must win since justice is on their side. In Frashëri's work, Muslim knights came to be related to Tomor, the emblematic Albanian mountain (see Spring Flowers XI: 53) and the Karbala battle was made an important event in Albanian minds. In the last canto, Frashëri suddenly forgot the Karbala story altogether and talked only about the key issues of the Albanian nationalist movement: the propagation of the language, learning and education, and the need for union and fraternity. There is even a sense that the first 24 cantos were written only to prepare the way for the Albanian question (see Xholi, 1998). For Frashëri, the meaning of the battle becomes as much human salvation as national liberation.

His Bektashi epic must be judged in the context of another of his monumental epics (History of Skanderbeg, 1898), in which he narrated the exploits, successes and failures of the Albanian national hero against Ottoman invaders in 15th century. This work is his most famous and is held to be his greatest poetic aspiration, a supreme attempt to project his idealism, patriotism and sense of Albanian cultural continuity back into the past, when for 25 years (1443-1468) Albanians had fought under Skanderbeg's leadership to resist Ottoman annexation. 
On the one hand, we have Skanderbeg, held to be the Albanian and European Christian symbol of resistance against Muslim Ottomans. On the other hand, in Shiite and Bektashi conceptions, we have Imam Ali, held to be inseparable from Muhammad, the founder of Islam. Astonishingly, however, Frashëri managed to overcome differences between the two faiths and recreate both Muslim martyrs and Albanian Christian fighters against Muslim invaders within the same symbolic world.

Qerbelaja and History of Skanderbeg were written at the same time, with the same pattern and in the same style, and were published in the same year. Just as Skanderbeg is the gravitational point of the History, other characters siding with or against him, Karbala is the lens through which the events and characters of Qerbelaja are projected. The religious epic is grounded on Muslim mythology and Eastern mysticism, while the heroic epic is based on Classic mythology and hierarchical figures of Christian symbolism. In both cases, by means of constructing such symbolisms, Frashëri shaped the system of values which constituted the core of his poetic and intellectual oeuvre. If Skanderbeg is the archetype of the fighter for his people's freedom, Imam Hussein is the archetype of the martyr for truth, and both are archetypes of fighters for justice. Both Skanderbeg and Imam Ali are personifications of good and light, while both Muawiya and the Muslim Ottomans are made the incarnation of evil and darkness. In fact, the setting for Qerbelaja is of the same black-and-white colouring as the setting for History of Skanderbeg; just the names are different. People in Qerbelaja are similar to people in History of Skanderbeg, and even the Muslim God in Qerbelaja is not dissimilar to the Christian God in History of Skanderbeg.

In History of Skanderbeg, Frashëri was concerned not with history, but with politics. He did not so much intend to clarify and highlight events of a certain period in Albanian history as to promote the political and revolutionary education of Albanians, to prepare them ideologically for the events of their time and of the future. Similarly, in Qerbelaja, instead of mythologizing and embellishing a local, historical and factual reality, Frashëri used the Karbala story as a local and historical metaphor of a mythic and ethical worldview.

The Karbala martyrs, quite contrary to historical evidence and Eastern tradition, owe much to the heroism of the romantic era, including Frashëri's own poetic portrayal of Skanderbeg (Norris, 1993: 182). Frashëri was not writing during the era of the poetic epos and its revival must have seemed a poetic anachronism. In fact, neither of the two epics had the same artistic importance as Frashëri's other poetic works, even though History of Skanderbeg became the poetic symbol of Albanian national pride. However, we may sense that at the time of writing they both had the same aim but were intended to reach different audiences. What made it necessary for Frashëri to provide Albanians with one or the other emblematic epos must have been his will to recreate the historical memory and heroic inspiration necessary to Albanian national ideology. In this sense, Frashëri's Qerbelaja was not necessarily an inertial expression of Eastern literary and religious traditions.

What makes Frashëri's Qerbelaja especially intriguing is that it aimed in some ways to deconfessionalize mystical Shiite religious symbols and themes so as to provide, alongside History of Skanderbeg, another grand narrative against Ottoman rule for an Albanian nationalism that transcended confessional allegiances. If the main idea of 
Qerbelaja, as a Bektashi-Islamic legend, is the clash between justice and injustice and the triumph of the former over the latter, clearly Frashëri wrote his religious epos not so much in order to create the 'sacred history' of Bektashism. Following the path of earlier religious translations by other nationalist activists, he went further in freeing history from dogma in order to attract believers to nationalism.

Among other things, the knowledge of God and divine light must be synonymous with public knowledge and national education and, clearly, Frashëri openly suggested and theorized the reconciliation of religion with the idea of the nation, even in the most religious of his writings. As in Qerbelaja's last canto, in his Bektashi Notebook he argued that the role of Bektashi leaders should be guided not only by 'love, brotherhood, unity', but also by 'friendship among Albanians'. In his words, 'the Bektashis are brothers with all people, they love at heart all other Muslims and Christians alike and they do well with all people, but above all they love their Motherland and the patriots as this is the best of the best'. Indeed, not only are Bektashi leaders guides on the path to God, but more importantly they must

strive night and day for the nation which calls them Fathers and urges them to work with the chiefs and the notables for the salvation of Albania and Albanians, for the education and civilization of their nation and their country, for their language and for all progress and improvement ... With chiefs and notables they must work for unity and fraternity among Albanians, to not let Muslims be divided from Christians, nor Christians from Muslims, but let them be and work together, for progress and improvement, for Albanians should not be ashamed, but be praised as before all over the world. (Bektashi Notebook)

\section{Intellectual activism and speculative literalism}

Frashëri was an eminent thinker and leading activist of Albanian Bektashism, Albanian romanticist enlightenment, the Albanian nationalist movement and Albanian literature. He disagreed with monasticism and strongly encouraged involvement with sociopolitical activities, holding that the basis of real belief in God was to serve the self-awareness of one's people. His significance as a nationalist poet rests upon the sociopolitical, philosophical and religious messages of national awareness not only among the Bektashis, but among all people in Albanian-speaking areas. There is sufficient evidence that Frashëri's works were from the beginning received with great interest and some of them held in high regard (Qosja, 1986: 479-481). He used simple language in his creative writing, so that uneducated people could grasp its meaning. Not only were his works intensively read at all ages, educational levels and religious affiliations, as they still are, but they also left their mark on popular culture, especially on oral poetry. Many of his poems became so popular during his lifetime that they were set to music and sung as folksongs in community celebrations or quoted as proverbs of common wisdom (Qosja, 1986: 29-30). Moreover, Albanian Bektashis often opened their ceremonies by reciting Frashëri's poems (Trix, 1993: 140).

His works, which he often had to sign only with his initials so as not to put himself in danger while working in a high official Ottoman position and which had to be smuggled into Albanian-speaking areas, circulated among Albanian readers as sacred books and 
many of his poems and some verses from his heroic epics, at least some time after publication, were often read aloud in groups and were intensively learnt by heart. Albanian nationalists awaited with eagerness the publication of the Skanderbeg epic, which had a great influence throughout the period of Ottoman domination. Just as History of Skanderbeg was widely read among readers of different levels and of three religions, Qerbelaja was held in high esteem by Bektashi readers and was read aloud during fasting by Albanian Bektashis. Their curiosity was surely aroused by the retelling of Muslim sacred stories, but if among Albanians there were already works on the Karbala battle written in accordance with the Eastern tradition and flooded with Ottoman vocabulary, the reading and recitation of Frashëri's Qerbelaja in purified Albanian was clearly a patriotic act, an open declaration of Albanian identity, emphasized by its concluding national appeal. After Qerbelaja, Albanian Bektashis must have been interested in Frashëri's other works and in other Albanian writers of the time. Among those interested in Albanian literature Frashëri must have introduced not just more readers, but readers of different levels and affiliations, including moral, political and religious connections (Qosja, 1986). Under the influence of his works these readers were won over to the cause of nationalist activism.

Undoubtedly, religious dogma, terminology and conceptual devices take an important place in Frashëri's oeuvre and inspiration. He continually addressed God as the divine and supernatural power in explaining everything related to human life, and the religious dimension is certainly a key to the essence of his creative world. Yet not only there is a flagrant contradiction between his creative writings and his educational works (Xholi, 1998: 35), but Frashëri's rationale was largely of humanist and nationalist interest. In his worldview, religious conceptions do not have a special role independent of his rationalist, humanist and nationalist ideology. He wrote very often about and took every opportunity to mention God, but very freely and even giving the divine a role in the liberating movement and national education of Albanians. Despite its mystical and religious universal symbolism, Frashëri's work shows a strong suggestive and motivational stance towards mobilization and national unity (Qerimi, 2000).

Arguably, if 'the language of Albanians is the language of God', his theological and intellectual speculations were very often part of a religious discourse easily acceptable to the masses, and were used as metaphors of worldly and national values. The meaning and significance of his ethical, religious and philosophical concepts and ideas are not in their direct semantic value, but in their functional and symbolic value. Frashëri's creative work is a search for universal and national ethics, where divine and historical schemes were made to represent current national situations and imperatives. This certainly does not mean that Frashëri was not a religious man, but as an activist thinker, he must have believed that some elements of religious faith could be put to work for the spiritual construction of a morally perfect Albanian society.

Frashëri dealt with being and knowledge as a moralist, and his work is simply a moral programme for building a new society based on goodness, wisdom and brotherhood, inspired by divine love. It is a very short step from this religious and moral idealism to the political idealism which is undoubtedly the core of his extensive and compelling educational and creative work. In fact, from the premise of the creation of a better world Frashëri moved to his sublime and steadfast aspiration to shake his fellow countrymen 
into achieving emancipation. It is this ideal, indeed, which fed his imagination and his musing, which made of him a mystic and inspired all his writings and all his life.

In talking of God Frashëri is not preaching or propagating religious dogma, but the moral dogma that is communicated through it. While a devout Muslim, Frashëri worshipped even Christ (Spring Flowers, IX), evoked as a symbol and martyr figure of grace, light, humanity, love, friendship and equality. Christ and the Muslim God embody what is the most humane and most noble, the ideal of the best. Whereas evil is the Devil incarnate, the good is the Muslim God incarnate in Christ. God's struggle with the Devil is a war between good and evil, the human and the inhuman, truth and untruth. With his concept of God, Frashëri does not necessarily manifest any religious and theological conviction, but both the Muslim God and Christ are symbols by which he addressed the universal embodiment of human moral excellence, equality, justice, love, brotherhood, humanism and freedom. His God opposed corrupt and immoral invading tyrants, to support and help the good and the oppressed. It is therefore quite understandable why Frashëri's God is always on the Albanian side, supporting their efforts for national liberation.

However, the cloaking of Frashëri's discourse in a specific Bektashi dress, together with his particularly religious, ritual and spiritual reception, seem to prevent local specialists from seeing that he addressed all Albanians in general and from understanding that he aimed to promote his nationalist ideas. Probably limited by the narrow contours of the very object of their studies, they may either overestimate or misunderstand the role of Bektashism in the context of Albanian nationalism. Nathalie Clayer, for instance, hastily and uncritically presents the construction of the Albanian nation as emanating exclusively from Bektashism (Clayer, 2002: 103-135), and mainly from its development under the influence of Frashëri and his brothers, even though she later came to slightly modify her position (Clayer, 2007). Similarly, as I have shown elsewhere in more detail (Doja, 2004), it is an exaggeration to argue, as Ger Duijzings (2000: 157-175) does, that Frashëri's attempt was to bridge the Albanian religious divide by proposing to turn Bektashism into an all-encompassing national religion for all Albanians.

Similar views are relayed or supported in the standard tradition of Albanian studies. However, such beliefs seem simply unsustainable in the face of what we know of the Albanian context. The Bektashis, in spite of their concentration in Albania, were a small minority quite marginalized within Sunni Muslims as well as within Albanian society in general, especially before the spread of the nationalist movement (Doja, 2006b). Frashëri was certainly not blind to this fact. I believe we can make better sense of Frashëri's message if we take the view that he did not intend so much to make a national myth of the Karbala martyrdom or to provide Albanians with a unique religion, but rather to make nationalist ideas acceptable to Albanian Bektashi and to Albanians of whatever religious affiliation, a position which Clayer has opportunely come to accept in her recent work (2007: 481). In all his oeuvre, and especially within History of Skanderbeg, Frashëri's intention was to forcefully appeal for union while playing down any manifest religious division or social and cultural differentiation among Albanians.

Leaving aside the curious statements of specialists who argue that 'Bektashi texts in general are relatively silent on points of social ethics' (DeJong, 1989: 10), what is more importantly lacking in their accounts is the analytical and anthropological imagination to 
understand Frashëri's poetic and intellectual speculations, especially in his Qerbelaja, which retells the saga of Shiism as the religion of victims of persecution. As in all his other works, these are relevant because they have been instrumental in shaping liberating theological ideas with gnostic and dualistic conceptions, derived mainly from the experience of suffering and related moral ideas.

\section{Bektashi liberation theology}

Following innovative approaches to early Sufism in the 11th and 12th centuries (Karamustafa, 1994; Trimingham, 1971), we may consider Bektashism primarily as a reaction against the external rationalization of religion in law and systematic theology. Essentially, like other early Sufi groupings, in its developments during the 13th and 14th centuries, Bektashism corresponded to the sphere of religious experience that developed from common experience of both spiritual knowledge and suffering, while running parallel and often in opposition to the orthodox institutional and mainstream Islamic consciousness that was derived from Prophetic revelation. Viewed in this light, as I have argued elsewhere (Doja, 2006c), the religious experience of the Bektashis likely shared characteristics of a liberation theology, while the structure of their groups corresponded to the type of religious organization conventionally known in sociology as charismatic groups.

An implicit reference is here made, of course, to Weberian sociology of religion (Weber, 1993), but considering Bektashism as a liberation theology and its followers as victims of persecution is also important because of its theological ideas, which were instrumentally shaped by Gnostic and dualistic conceptions. In particular, anthropologists know, after Lévi-Strauss and Clifford Geertz, how moral ideas, dualistic conceptions and liberating theologies can develop from the experience of suffering. The discrepancy between moral prescriptions and material rewards in various aspects of human experience and the concern with this intractable ethical paradox are the expression of an issue that animated the Book of Job and that is alive in almost every religious system. Even though Lévi-Strauss's demonstration of the sustaining 'effectiveness of symbols' (1958) is concerned with shamanism and Geertz's statements (1973a) seem to reflect concerns from a Protestant Christian reference point, I believe they can provide a better understanding of the philosophical and theological dimensions of the problem of suffering as a religious problem in Islamic contexts, with particular attention to Shiite and Bektashi concerns.

Religious responses to the uncomfortable suspicion that perhaps the world and human life have no genuine order or moral coherence at all are in each case the same: the formulation, by means of religious symbolism, of an image of world order that relates human experience to a wider sphere within which it is conceived to rest. The effort is not to deny that there are unexplained events or that life hurts, but to deny that there are inexplicable events, that life is unendurable, and that justice is a mirage. Most often, this effort takes shape in a set of notions about 'division' in the world.

A case in point is explicitly articulated in Frashëri's creative writings where the world is torn between fundamental oppositions: on one side is the hero, God, representing the good, truth and light; on the other is the Devil, representing evil, untruth and darkness. Similarly for Frashëri, human life lies between birth and death, father and son, youth and 
old age, health and disease. Therefore, all his writing symbolizes good or evil, construction or destruction, freedom or slavery (see Qerimi, 2000; Qosja, 1986).

Especially in Frashëri's Islamic speculations in Qerbelaja, events and characters attain a moral appearance of being true and real in the same way that beliefs of good and evil are transmitted by the Shiite and Bektashi oral tradition. Similarly, in History of Skanderbeg, in spite of his Muslim allegiance and his high official position in the Ottoman Empire, Frashëri elaborated comparable Christian hierarchical symbols to show that the representation of spiritual good was resolutely the Albanian Christian knight, whereas Muslim Ottomans were inevitably turned into the embodiment of evil.

In his heroic epic, Frashëri's ethic and poetic interest is focused on showing the characters aligned in two groups that represent opposed ethical categories. In the group of good are Albanians, Skanderbeg and his comrades-in-arms, who fight for their national freedom and existence, whereas in the group of evil are Ottoman Muslims, successive Sultans and their soldiers, who undertake invasive military campaigns against Albanians. On the Albanian side there is only wisdom, courage, freedom-loving, patriotism, union and the moral victory of good, light, truth and justice over the evil, darkness, untruth and injustice that remain on the Ottoman Muslim side. Albanian characters may belong to different historical periods, but they represent a unique mythical time of the Albanian nation when evil was overcome by good. From the start, an idyllic view of Albania is conveyed: a flourishing country where brave and virtuous people lived in a golden age cut off by the advent of the Ottoman Muslims. They brought murder and destruction, their darkness assaulted the light, and their lack of enlightenment offended wisdom, for only the Devil could find space in the world. Frashëri repeatedly shows how Muslim Ottomans 'were evil in their heart', massively embodying any vice and abjection 'coming from Devil' (History of Skanderbeg, I: 85-100).

However, this division is everywhere a metaphorized contradiction. The central figure of Skanderbeg and other characters are static, unvarying, without any evolution in the course of events. Independent of the milieu where they are born and grow up, live and die, independent of the culture into which they are mentally and morally construed, independent of the group of which they are members, independent even of their age and gender, the characters are general patterns situated out of time and out of space (Qosja, 1986: 244). Their differences are affected only by another factor that Frashëri supposed to be ahistoric, naturally created once and for all. In History of Skanderbeg, Frashëri constructed with Western Christian spiritual concepts the representation of moral and ideational symbols that show characters clearly divided, because they are conceived from the starting point of the infinite antagonist division of good and evil. As in his philosophical poetry, throughout which concepts of good and evil, light and darkness, knowledge and ignorance, truth and untruth are elaborated, his heroic characters are specifically shown never to be neutral in their deeds, behaviour or thinking, but good or evil, enlightened or unenlightened, committed to truth or to untruth.

Similarly, in Qerbelaja, religious characters and events are meant by Frashëri to construct primarily a mythological rather than a historical model of the world. His ethic and poetic interest is focused on showing the characters aligned in the same two groups that represent the opposed ethic categories. Every character is supposed to actualize those virtues and vices that embody Frashëri's moral teachings, as shown throughout his other 
writings. On the side of good is Imam Ali with his sons and followers, who are the embodiment of the best human virtues in their attitudes and actions, whereas in the group of evil are their enemies, who show the worst human vices, evil, malice, iniquity, devilry and atrocity in all their deeds. In Bektashi and Shiite memory, the unequal battle of Imam Hussein and his followers at Karbala is made emblematic of the eternal battle for good, truth and human justice against evil, untruth, injustice and the insatiable voracity of power.

Like his other philosophical and poetical verses, both his religious and heroic epics show clearly that Frashëri's thought is based on the dualist worldview of opposed forces working in human life, in history, in nature - indeed, everywhere. The world of his creative writings is a poetic actualization of the cosmological principle of the battle between good and evil, God and the Devil, truth and untruth, light and darkness, knowledge and ignorance, magnificence and viciousness. He is primarily interested in the illustration and actualization of these ethical oppositions, as much on the universal human level as on the local, historical and national level. In Qerbelaja, the 'division' of the world exists from the origins, having its own ontological, cosmological and anthropological consistency of which no explanation is attempted, but a strong assertion is given without any margin for ambiguity:

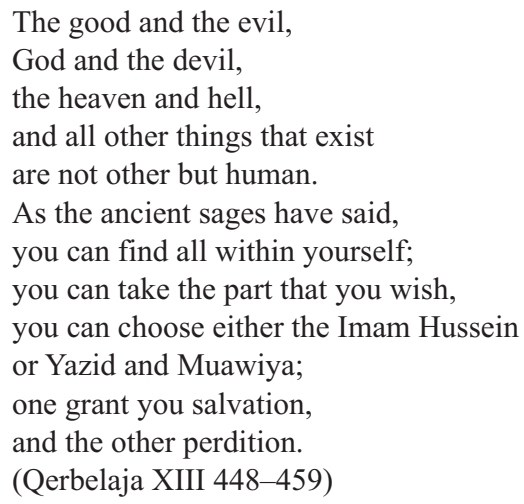

Because the mysterium iniquitatis of why the world and worldly life are 'so repugnant' (Qerbelaja, XIV: 27) is unassailably at the forefront of his attention, in Frashëri's thinking and understanding of Bektashi conceptions the world is clearly separated into good and evil, just as humankind is divided into the human and the inhuman, into the oppressed and oppressors, into freedom fighters and invaders. Tainted by the pathos of pain, many of Frashëri's autobiographical poetic musings show clearly his deep suspicion of divine justice: 'Where do you have, O Heaven, your justice; where is your mercy, grace and generosity?' (Reveries, XXIV: 15-16) 'Thou Heaven, unashamed and traitorous, heartbreaking, unjust and bloodthirsty!' (Reveries, XXII: 31-32). Indeed, while in a profound crisis of physical and spiritual distress, in a letter addressed to his brother on 15 April 1877, Frashëri went so far as to write down his explicit belief in the existence of the Devil (his own ellipsis is significant): 'I feel very bad, but with the Devil's will, I hope the hassle will come to an end. I've got to beseech the Devil for relief. I believe there is a Devil, as ... does not exist' (Works, VI: 345-346). 
In fact, from the experience of suffering, the 'division' of the world epitomizes various conceptions of the Devil. Divergent concepts of the Devil in Jewish and Christian theology notwithstanding, in both the Christian and Islamic traditions Satan is the fallen celestial being, who for his pride is cut off from God and driven to despair, while at the same time he is made to work on God's behalf (albeit unwittingly) by testing, tempting and even deceiving humans, or leading them astray by exploiting their arrogance. Viewed either way (as a fallen angel doing God's dirty work or as an intrinsic human tendency towards sin or evil) on the ethical level, the Devil performs a vital function in humanity's fulfilment of its potential. It presents humans with choices that allow them to make moral decisions and in so doing move closer to God.

Yet, even in his most religious poem, Frashëri went on to explicitly express his doubts as to the immortality of eternal spirit, which is obviously related to a suspicion of the impotence of a supposedly eternal and omnipotent God: 'With so much hope of everlasting fulfillment, how can Man fall from life and die? How can life come to an end? Is there no other place somewhere? Shall we be back here again? Where shall I find the answer?' (Qerbelaja, XIII: 425-430).

If the power of God suffers an obvious limitation or division, justifying a suspicion of either impotence or malice, this would make it possible, and therefore necessary, to interpret this malicious or not-so-omnipotent God as the 'second God' of Gnosticism and dualism (see Guidetti, 1998). Indeed, on the theological level, the necessity for the existence of both God and the Devil ultimately leads to the antagonist duality of supreme and subordinate divinities in Gnosticism and other dualistic theological systems, similar to the founding principle of the ancient Iranian dualistic religions of Zoroastrianism and Manichaeism.

This is important, as dualism has offered conceptual problems for orthodox religions because orthodoxy claims emphatically to be monotheistic, but also because it is conceptually seen as a likely cause of violence. The image of Satan in Christian societies across history is well known, particularly as it pertains to the Inquisition and the witch trials that haunted many Christian societies in Europe. The Church's need to stamp out dissent, discipline and control potentially restive populations, and enforce orthodoxy against various forms of heretical folk Catholicism and Protestant sects made Satan a central player in the Christian drama during the last millennium. Similarly, we must take into consideration all those Muslim thinkers, theologians and mystic poets, who opposed dualism, often very fiercely, on the grounds that it is anathema to God's oneness.

However, there is a dualistic streak especially in Twelver Shiism, perhaps under the influence of Iran's own past, which must have been transmitted to Bektashism as well and which must have served as a blueprint for militancy, because it encouraged selfrighteousness and goodness, by referring to others as 'evil' that needs to be cleansed. In the Karbala battle, as in the Albanian struggle against the Ottomans, both Shiite martyrs and Albanian heroes endured a kind of divinization. In the process they came to fulfil a function of encouragement to a painful fight for liberation and the escape of the divinized spirit from evil and worldly imprisonment. This is precisely where 'the heart of gnosis pulsates' (Bianchi, 1983: 15).

In this way, dualism can easily lead to violence as a generic means for justifying nationalism and other forms of otherization. Indeed, underlying such violence is a 
good-versus-evil view of the world. And this dualistic worldview must have been in Frashëri's mind, as God and the Devil are words he used quite often in his creative and educational writings. This must have been the way for Frashëri to see the selfrighteousness of Christian Albanian fighters against Ottoman evil, which should lead Albanians to consider that the Devil was incarnated by Muslim Ottomans. Similarly, the self-righteousness of Imam Hussein and the other Karbala martyrs is worked out more specifically in order for the Bektashis to consider that the Devil is Muawiya and his offspring.

Much the same kind of self-righteousness is claimed by Bektashis for Hadji Bektash himself as a young soldier in the Babaî revolts, for Alevi-Kizilbash during the OttomanSafavid wars in the 16th century and for Alevi-Bektashi, taken to be systematically oppressed by political or religious authoritarian regimes. The heterodox, antinomian and separatist background of Bektashism as an extremism of Islam is claimed to explain the continual massacres to which its followers have been subjected, depending on their whereabouts and specific history, as examined elsewhere (Doja, 2006a). Already in the late 16th century and probably in much the same vein, the ideological basis of the Iranian dynasty exposed to the hostility of Ottoman power was rooted in the political promotion of mystic extremist Shiism and messianic Turkic beliefs drawn from those Kizilbash elements that would subsequently permeate Bektashism.

\section{Concluding remarks}

Though I am fully aware that the above-mentioned connections to religious worldviews are not clearly apparent - and when one is dealing with traditions of Islamic mysticism it is even more difficult to make such clear associations - it is my contention that it is precisely around such connections that Frashëri's intellectual speculations were centred. References common in much Sufi thought to Shiite-Safavi phenomena and Ottoman-era Sufi practice, development, and thought from the 16th century to Frashëri's own time are intuitively re-enacted in his work as part of the intellectual and ideational environment within which he wrote. In his creative writings he borrowed, poetically elaborated and further developed the ethical dualism of Manichean oppositions, and through them he tried to induce the willingness of Albanians to sacrifice themselves for their nation, boosting the belief that only through resilience and resistance against foreign invaders might they overcome the oppression to which they had been subjected for centuries.

Another issue to be taken into account, however, is that even in Iranian Shiism dualism was and still is problematic. The juxtaposition of Imam Hassan and Imam Hussein is just one manifestation of this tension. Dualist militancy and peaceful Gnosticism and Universalism coexisted in tension and at higher levels of abstraction as an endeavour toward mature goodness (kamal) stage by stage. Therefore, unless one adopts a dialectical approach as opposed to the dichotomist position in the very notion of Manichean dualism, an argument that posits Frashëri's humanism and nationalism exclusively on Bektashi heterodoxy, or any other kind of dualism, would remain partial and eventually unconvincing. After all, Hadji Bektash himself, in the latter part of his life, is represented in his Vilayet-Name as a person who could keep together in peace the lion and the lamp in his 'lap' (Golpinarli, 1958), because he was close to God. In addition, a dialectical 
position is systematically assumed in Bektashi teachings, where all human beings have the 'clay' and the 'grace' (nafas) of God in them and they struggle to make divine grace prevail over their earth(l)y side, while this struggle is both a test and a credit (amana) to them.

Clearly, there are different approaches to explaining the Devil's place in the scheme of things and one would be surprised if Frashëri was not aware of them. In fact, most of his verses, from Spring Flowers to Qerbelaja, constantly show the extent to which in his conception 'both Heaven and Hell, both Angel and Devil, and anything else that exists, all are within the living' (Spring Flowers, XIX: 41-44), as everybody has a streak of goodness and evil in themselves, but also the extent to which they must move towards good:

The Angel and its good,

The Devil and its evil,

All are in one place;

You may take what you wish,

Wise goodness is the way

That brings us to God ...

Wise humanity is the way

That brings us to God.

(Qerbelaja XXV 53-58,129-130)

However, the best way for Frashëri to overcome Manichaean dualism and build his nationalist ethics was to take on board another heterodox trait from Bektashism, namely pantheism, which for both orthodox Islam and Christianity is traditionally taken as a heretical belief. While the contextual analysis of these developments in Frashëri's work must be examined in more detail at another time, it is important to note here that Bektashi pantheism is not only fully acknowledged but even furthered in Frashëri's national ethics, following a long tradition of Universalism within Sufism as we know it from Hodgson's discussion of later Sufism in the Muslim East (Hodgson, 1974).

From a comparative Islamic studies and Islamic politics perspective, Frashëri's use of Shiite and Sufi themes and symbolism did not preclude what was, by any measure, an eclectic heterodox fusion of religious and spiritual elements. He was working with some classical ideas which others before him had reflected on at a highly sophisticated level and which before long popular teachings would adopt and convey to followers through anecdotes and poems. Frashëri's ideas may go back to the ninth century and they have since become standard teaching at higher levels of Sufi learning and experience. Nevertheless, even though many dedicated Sufi or Bektashi would fully agree with most of his ideas, no one would jump to the conclusions he arrived at.

In the formulation and argumentation of his philosophy, Frashëri made use of both religious and realist, both pantheistic and Gnostic conceptions, coming from both Eastern and Western traditions. In matters of theological doctrine, he brought about with his oeuvre a new conception of the divine, arguably much more heretical than heterodox Bektashism. He seems to have gone so far as to be in sharp contrast to, and even to reject, the authority of orthodox and formalistic interpretations of the Koran, the sacred book of Islam. Though by means of traditional themes, Frashëri could even protest against God 
and leave him out of the picture, which would be unusual for a Bektashi - at least, it would be a difficult line to cross and still remain a Bektashi. In fact, as a modern intellectual who took some of the core ideas and inspirations of Bektashism seriously, Frashëri took some interesting and important steps in his teaching, overtly moving away from a classical vision, narrowing it or enlarging it, depending on which way one looks at his ideas.

To this extent, it can be argued that the combination of dualism and pantheistic ideas might have made it possible for Bektashism to join with Albanian nationalist ideology. The articulation of contest and liberation ideologies with the hierarchization of covenantal structures of divine mediation is particularly helpful at revealing the organizational and theological character of Bektashism as a mystical, heterodox order. Throughout its historical transformations, this very aspect can be thought to have set Bektashism against the Sunni monotheism that served Ottoman imperial centralism. Arguably, this can provide a rationale for Frashëri's Albanianism and, alongside many other factors, go some way to helping us understand the character of Albanian nationalism, which generally lacked strong religious attachments.

The specific cultural and political instrumentality of religion exhibited by 19th-century Albanian nationalism certainly appear unusual, and difficult to grasp, if one schematically employs traditional categories, as developed in current scholarship dealing with these questions. However, an articulate combination of the main nationalist projects and intellectual speculations, linked to a careful examination of the historical and literary contextualization in a comparative political perspective, is likely to produce a more sophisticated understanding of the myth of the relationship of Bektashism to the emergence of Albanian nationalism.

While analyzing the historical, cultural and literary terrain in which certain influential ideas in Albanian intellectual history emerged, the aim of this article was to frame the argument in such a way as to break the close association of a major figure of Albanian nationalism with Bektashism and to present Frashëri as an intellectual whose literary and intellectual output is about national values and nation-building endeavours. More simply, as an implication of my discussions in this paper, Frashëri is an Albanian nationalist figure of whom the Bektashi have emphasized the Bektashi heritage so that they themselves could appear more loyal to and perhaps even better situated to claim a contribution to issues of nationhood than either Sunni Muslims or Orthodox Christians of Albanian descent.

In methodological terms, I tried to engage with a comparative analysis of ideas rather than with a search for positive literal proof. This approach might not be exhaustive, and certainly a number of questions remain open. However, if this article has managed to provoke at the very least a non-stereotyped discussion throughout an interesting set of cogent reflections on Frashëri and the association of Bektashism with the emergence of Albanian nationalism, it will hopefully constitute a starting point for further, deeper enquiries, which may yield alternative explanations.

\section{Funding}

This research received no specific grant from any funding agency in the public, commercial, or not-for-profit sectors. 


\section{References}

Ayoub M (1978) Redemptive Suffering in Islam. Hague: Mouton.

Barth F (1969) Introduction. In: Ethnic Groups and Boundaries. London: Allen and Unwin, 9-38.

Bartl P (1968) Die albanischen Muslime zur Zeit der nationalen Unabhängigkeitsbewegung.

Wiesbaden: Harrassowitz.

Bianchi U (1983) Il dualismo religioso. Rome: Ateneo.

Birge JK (1937) The Bektashi Order of Dervishes. London: Luzac.

Bourdieu P (1971) Genèse et structure du champ religieux. Revue Française de Sociologie 12(3): $295-334$.

Clayer N (1990) L'Albanie pays des derviches. Wiesbaden: Harrassowitz.

Clayer N (1994) Mystiques, État et Société. Leiden: Brill.

Clayer N (2002) Religion et nation chez les Albanais. Istanbul: Isis.

Clayer N (2007) Aux origines du nationalisme albanais. Paris: Karthala.

DeJong F (1989) The iconography of Bektashism. Manuscripts of the Middle East 4: 7-29.

Doja A (1999) Ethnicité, construction nationale et nationalisme dans l'aire albanaise. Ethnologia Balkanica 3: 155-179.

Doja A (2000a) Histoire et dialectique des idéologies et significations religieuses. European Legacy 5(5): 663-686.

Doja A (2000b) The politics of religion in the reconstruction of identities: the Albanian situation. Critique of Anthropology 20(4): 421-438.

Doja A (2004) Cultural politics and spiritual making of anthropologists. Reviews in Anthropology 33(1): 73-94.

Doja A (2006a) A political history of Bektashism from Ottoman Anatolia to Contemporary Turkey. Journal of Church and State 48(2): 421-450.

Doja A (2006b) A political history of Bektashism in Albania. Totalitarian Movements and Political Religions 7(1): 83-107.

Doja A (2006c) Spiritual surrender: from companionship to hierarchy in the history of Bektashism. Numen 53(2): 448-510.

Duijzings G (2000) Religion and the Politics of Identity in Kosovo. London: Hurst.

Geertz C (1973a) Religion as a cultural system. In: The Interpretation of Cultures. New York: Basic Books, 87-125.

Geertz C (1973b) Thick description: Towards an interpretation theory of culture. In: The Interpretation of Cultures. New York: Basic Books, 3-30.

Golpinarli A (1958) Menakibi Haci Bektashi Veli: Vilayet-Name. Istanbul: Inkilap.

Guidetti V (1998) Elementi dualistici e gnostici della religione Bektashi in Albania. In: Destino e salvezza. Cosenza: Giordano, 239-264.

Hasluck F (1929) Christianity and Islam under the Sultans. Oxford: Clarendon.

Hodgson M (1974) The Venture of Islam. Chicago: University of Chicago Press.

Karamustafa A (1994) God's Unruly Friends. Salt Lake City: University of Utah Press.

Kressing F (2002) A preliminary account of research regarding the Albanian Bektashis. In: Albania: a country in transition. Baden-Baden: Nomos, 65-91.

Lévi-Strauss C (1958) L'efficacité symbolique. In: Anthropologie structurale. Paris: Plon, 205-226.

Melikoff I (1998) Hadji Bektach un mythe et ses avatars. Leiden: Brill.

Moosa M (1988) Extremist Shiites. New York: Syracuse University Press.

Morozzo della Rocca R (1990) Nazione e religione in Albania. Bologna: Mulino.

Norris H (1993) Islam in the Balkans. London: Hurst.

Norris H (2006) Popular Sufism in Eastern Europe. London: Routledge.

Norton J (2001) The Bektashi in the Balkans. In: Religious Quest and National Identity in the Balkans. New York: Palgrave, 168-200. 
Popovic A (1986) L'islam balkanique. Wiesbaden: Harrassowitz.

Popovic A and Veinstein G (1995) Bektachiyya: études sur l'ordre mystique des Bektachis et les groupes relevant de Hadji Bektach. Istanbul: Isis.

Qerimi B (2000) Poetika Naim Frashërit [The Poetics of Naim Frashëri]. Tirana: Toena.

Qosja R (1986) Porosia e Madhe: Monografi mbi Krijimtarinë e Naim Frashërit [The Great Commandment: a Monograph on the Works of Naim Frashëri]. Prishtina: Rilindja.

Rexhebi B (1970) Misticizma Islame dhe Bektashizma [Islamic Mysticism and Bektashism]. New York: Waldon.

Skendi S (1967) The Albanian National Awakening. Princeton: Princeton University Press.

Stadtmüller G (1971) Der Derwischorden der Bektaschi in Albanien. In: Serta Slavica. Munich: Trofenik, 683-688.

Trimingham JS (1971) The Sufi Orders in Islam. Oxford: Clarendon.

Trix F (1993) Spiritual Discourse. Philadelphia: University of Pennsylvania Press.

Turabiu A (1929) Historia pergjithshme Bektashinjvet [General History of the Bektashis]. Tirana. Wach J (1958) Sociology of Religion. Chicago: University of Chicago Press.

Weber M (1978) Economy and Society. Berkeley: University of California Press.

Weber M (1993) The Sociology of Religion. Boston: Beacon.

Wilson B (1990) The Social Dimensions of Sectarianism. Oxford: Oxford University Press.

Xholi Z (1998) Naim Frashëri midis së kaluarës dhe së sotmes [Naim Frashëri between past and present]. Tirana: Luarasi.

\section{Author biography}

Albert DOJA is a University Professor of Sociology and Anthropology at the University of Sciences and Technologies of Lille, France. He is also a full Ordinary Member of the Albanian Academy of Sciences and holder of the first Chair of Social Anthropology. He has held several academic positions in France, Britain, Ireland and Albania, where he has lectured social anthropology. He is an editorial board member of international academic journals. His special interests include the politics of knowledge; identity and religion; power and ideology; the anthropology of symbolism and communication; technologies of the body, personhood, gender construction, kinship and reproduction activism; intercultural communication, interethnic relations and international migrations; ethnicity and nationalism; cultural heritage and social transformations; the anthropology of history; anthropological theory, structural analysis, post-structuralism and neo-structuralism.

Address: Institute of Sociology and Anthropology, University of Sciences and Technologies of Lille 1, Cité Scientifique SH2-215, 59655 Villeneuve d'Ascq, Cedex, France.

Email: albert.doja@univ-lille1.fr. 